УДК 811.111 '42

DOI https://doi.org/10.26661/2414-1135-2021-82-14

\title{
НЕОЛОГІЗМИ В АНГЛОМОВНОМУ ДИСКУРСІ ПАНДЕМІЇ СОVID-19
}

\author{
Іванців О. В. \\ кандидат філологічних наук, \\ доиент кафедри теорії і практики перекладу \\ Тернопільський національний педагогічний університет імені Володимира Гнатюка \\ вул. М. Кривоноса, 2, Тернопіль, Украӥна \\ orcid.org/0000-0003-4956-6278 \\ orysya_ivantsiv@yahoo.com
}

Катрич Т. C.

студентка IV курсу факультету іноземних мов

Тернопільський національний педагогічний університет імені Володимира Гнатюка

вул. М. Кривоноса, 2, Тернопіль, Україна

orcid.org/0000-0002-3104-6920

meyandmasha@gmail.com

\begin{abstract}
Ключові слова: англомовний дискурс пандемії COVID-19, типологічні характеристики дискурсу, неологізми, структура неологізмів, семантичні особливості неологізмів.
\end{abstract}

У статті розкрито специфіку сучасного англомовного дискурсу пандемії COVID-19 і структурно-семантичні характеристики неологізмів, які вживаються в межах цього дискурсу. Актуальність дослідження полягає в стрімкому збільшенні кількості текстів коронавірусної тематики на фоні чинної пандемічної кризи та появі в них численних новотворів на позначення явищ COVID-19. Дискурс пандемії COVID-19 $є$ актуальним феноменом мисленнєво-мовленнєвої діяльності індивідів, який утворився на тлі подій 2019-2021 рр.. Він сформувався в результаті комунікації між учасниками різного статусу (професіоналами й цивільними громадянами), об'єднавши фонди знань про коронавірус у різних сферах людської діяльності (епідеміології, політики, економіки, бізнесу, психології тощо), оскільки пандемічна ситуація не лише справила величезний вплив на систему охорони здоров'я, а й докорінно змінила інші аспекти життя індивідів. Головною метою продуцентів англомовного дискурсу пандемії COVID-19 є підвищення суспільної свідомості щодо серйозності ситуації та глобальної важливості дотримання карантинних норм та обмежень задля запобігання поширенню коронавірусу й збереження життя і здоров'я людей. Досліджуваний дискурс має гібридну природу, оскільки в ньому інтегруються й перетинаються ознаки різних типів дискурсу, а саме: медичного, політичного, економічного, психологічного, освітнього, туристичного та побутового. Англомовний дискурс пандемії COVID-19 характеризується високим впливогенним потенціалом, мультимодальністю й неогенністю. Тексти коронавірусної тематики вирізняються насиченістю новими словами та словосполученнями, використання яких значно поширилося засобами масової інформації. За структурою досліджувані неологізми - це складні слова, більшість із яких утворені поєднанням або скороченням двох основ. Вони позначають нові реалії життя, безпосередньо пов'язані з пандемією COVID-19. 


\title{
NEOLOGISMS IN ENGLISH DISCOURSE OF COVID-19 PANDEMIC
}

\author{
Ivantsiv O. V. \\ Candidate of Philological Sciences, \\ Associate Professor at the Department of Translation Theory and Practice \\ Ternopil Volodymyr Hnatiuk National Pedagogical University \\ M. Kryvonosa str., 2, Ternopil, Ukraine \\ orcid.org/0000-0003-4956-6278 \\ orysya_ivantsiv@yahoo.com
}

Katrych T. S.

Student of the 4th year at the Faculty of Foreign Languages

Ternopil Volodymyr Hnatiuk National Pedagogical University

M. Kryvonosa str., 2, Ternopil, Ukraine

orcid.org/0000-0002-3104-6920

meyandmasha@gmail.com

Key words: English discourse of COVID-19 pandemic, typological characteristics of discourse, neologisms, structure of neologisms, semantic features of neologisms.

\begin{abstract}
The article focuses on the specific features of the present-day English discourse of the COVID-19 pandemic and the structural and semantic characteristics of neologisms used within this discourse. The relevance of the study lies in the rapid increase in the number of texts on coronavirus issues during the current pandemic crisis and the emergence of numerous neologisms denoting the COVID-19 phenomena. The discourse of the COVID-19 pandemic is a new product of mental and speech activity of individuals, which was created during the events of 2019-2021. It was formed as a result of communication between participants of different status (professionals and civilians) integrating knowledge of coronavirus in different areas of human activity (epidemiology, politics, economics, business, psychology etc.) as the pandemic situation has had a huge impact not only on the health care system, but also radically changed other aspects of individuals' lives. The main goal of the addressers of the English discourse of the COVID-19 pandemic is to raise public awareness of the seriousness of the situation and the global importance of following quarantine regulations and restrictions to prevent the spread of coronavirus and save lives and protect human health. The studied discourse has a hybrid nature as it integrates the features of various types of discourse, namely medical, political, economic, psychological, educational, tourist and domestic discourse. The English discourse of the COVID-19 pandemic is characterized by a high influential potential, multimodality and neogeneity. Coronavirus texts are saturated with new words and phrases, the use of which has become widespread in the media. According to their structure the studied neologisms are compound words, most of which are formed by blending or clipping of two stems. They nominate new realities of life directly related to the COVID-19 pandemic.
\end{abstract}

Постановка проблеми. У межах когнітивно-дискурсивної парадигми сучасного мовознавства існує тенденція до поглибленого дослідження особливостей організації комунікативної взаємодії. Саме тому у фокусі уваги дослідників опинилася категорія дискурсу та посилився інтерес до аналізу його різновидів. У зв'язку з тим що сьогодні світ переживає глобальну небезпеку для здоров'я людей, спричинену новою хворобою під назвою COVID-19 (Coronavirus disease-2019), чільне місце в загальному спектрі дискурсів посідає новостворений дискурс пандемії COVID-19.

Оскільки коронавірусна криза докорінно змінила стиль життя людей, це не могло не відобразитися на лінгвістичній ситуації. Сучасний соціальний контекст, пов'язаний із пандемією COVID-19, вплинув на те, що англійська мова поповнилася новими словами і словосполученнями й новими значеннями раніше наявних мовних одиниць, а їх використання значно поширилося засобами масової інформації. 
У працях сучасних мовознавців представлено аналіз способів творення неологізмів коронавірусної тематики в межах епідеміологічного дискурсу (О. Бабелюк, Л. Дідух [1]), дослідження лексичних інновацій, пов'язаних із пандемією COVID-19, у контексті медійного дискурсу (Т. Весна, Т. Телецька [2]) і розгляд концептуальних метафор на позначення коронавірусу (К. Красницька, Н. Степанюк, Н. Долусова [3]) тощо.

Актуальність дослідження полягає в стрімкому збільшенні кількості текстів коронавірусної тематики на фоні чинної пандемічної кризи та появі в них численних неологізмів на позначення явищ COVID-19.

Мета й завдання статті. Мета наукової розвідки полягає у виявленні специфіки англомовного дискурсу пандеміі COVID-19 та аналізі структурно-семантичних особливостей лексичних новотворів, які вживаються в межах цього дискурсу. Досягнення поставленої мети передбачає розв'язання таких завдань: 1) визначити сутність і статус новоствореного англомовного дискурсу пандемії COVID-19 у дискурсивній матриці; 2) проаналізувати структурно-семантичні характеристики неологізмів англомовного дискурсу пандемії COVID-19.

Предмет та об'єкт дослідження. Об'єктом дослідження $є$ англомовні неологізми, що створені або зазнали розширення значення на тлі пандемії коронавірусу, які вживаються в межах дискурсу пандемії COVID-19. Предметом дослідження $\epsilon$ структурно-семантичні особливості неологізмів новоствореного англомовного дискурсу пандемії COVID-19.

Виклад основного матеріалу дослідження. Одним із актуальних феноменів мисленнєвомовленнєвої діяльності індивідів, який утворився на тлі подій 2019-2021 рр., став дискурс пандемії COVID-19. Він сформувався в результаті комунікації між учасниками різного статусу (професіоналами й цивільними громадянами), об'єднавши фонди знань про коронавірус у різних сферах людської діяльності (епідеміології, політики, економіки, бізнесу, психології тощо), оскільки пандемічна ситуація не лише справила величезний вплив на систему охорони здоров'я, а й докорінно змінила інші аспекти життя індивідів. Головною метою продуцентів англомовного дискурсу пандемії COVID-19 є підвищення суспільної свідомості щодо серйозності ситуації та глобальної важливості дотримання карантинних норм та обмежень задля запобігання поширенню коронавірусу й збереження життя і здоров'я людей.

Англомовний дискурс пандемії COVID-19 є складним типом дискурсу, гібридною субстанцією, яка характеризується інтеграцією ознак різних типів дискурсу, а саме: медичного, полі- тичного, економічного, психологічного, освітнього, туристичного й побутового - і реалізується на їх перетині.

На основі типології ознак епідеміологічного дискурсу [1, с. 6] ми виділили характерні риси досліджуваного дискурсу, до яких належать впливогенний потенціал (здатність здійснювати комунікативний вплив на свідомість адресата шляхом побудови раціональної аргументації (переконування) та емоційної аргументації (емоційне зарядження) і на підсвідомість через сугестію (навіювання) [4, с. 132]), мультимодальність (інтеграція вербальних і невербальних засобів вираження змісту (графіки, фотографій; аудіо-, відеоматеріалів, анімаційних та інших мультимедійних форматів фіксації інформації) [4, с. 58]) і неогенність (насиченість текстів коронавірусної тематики лексичними новотворами).

Виникнення неологізмів демонструє динамічність мови та ії пристосування до кризових ситуацій і змін у суспільстві. Пандемія коронавірусу докорінно трансформувала стиль життя світової спільноти, вимагаючи пристосування до нових соціальних правил і патернів поведінки. Цей вірус вразив мільйони й забрав тисячі життів людей. Хвиля страху, занепокоєння та невизначеності в суспільстві спричинила появу в англійській мові понад 1000 нових слів і висловів на позначення явищ COVID-19 [1, с. 5].

Протягом перших тижнів швидкого поширення коронавірусу урядам багатьох країн довелося прийняти низку нагальних рішень для ефективної боротьби 3 ним. Саме в умовах карантинних обмежень, які тривають уже більше року, коли кожен наступний день схожий на попередній, i виникло слово blursday (з англ. blurred - нечіmкий i day - день): "I'm not sure what day is it today. It's a Blursday" [6]. Щороку лексикографи 3 провідного світового видавництва словників Oxford Languages, що створюють Oxford English Dictionary, вибирають одне слово або фразу, що описує останні 12 місяців. У 2020 році неологізм blursday увійшов у цей почесний список [5].

Поява досі невідомої світу хвороби COVID-19 і недостатність інформації про вірус призвели до активізації користувачів мережі Інтернет. Кожен намагався дізнатися про те, як пандемія вплине на соціальні процеси й охорону здоров'я. Згодом почало з'являтися дедалі більше дезінформації та антиутопічних новин, що й призвело до активнішого використання неолексеми doomscrolling (з англ. doom - загибель і scrolling - гортання), яка описує процес споживання великої кількості негативних новин в Інтернеті за короткий проміжок часу: "If you're are prone to anxiety, depression or sadness, doomscrolling can be like stepping into quicksand" [7]. 
У зв'язку з тим що пандемія COVID-19 змусила багатьох людей залишатися вдома, відеоконференції почали широко використовуватися в освітніх i професійних цілях. Найбільшої популярності набула програма для організації відеоконференцій Zoom. Zoombombing (з англ. zoom - програма для відеозв' язку та bombing - бомбардування) - це процес втручання хуліганами у відеодзвінок на платформі Zoom: "Some of the measures that people would think stops zoombombing - such as requiring a password to enter a class or meeting - did not deter anybody" [8]. Характерний процес розіграшу містить надсилання матеріалів непристойного, расистського, гомофобного або антисемітського характеру, що зазвичай призводить до припинення сеансу відеозв'язку. Крім того, з'явився інший неологізм - zoom fatigue (zoom - програма для відеозв'язку та fatigue - втома) - для позначення психічного виснаження, пов'язаного 3 постійними відеоконференціями: Oh man, I've had so many Zoom meetings this week I'm feeling Zoom fatigue [9]. Обидва новотвори стосуються використання будьякого сервісу для відеоконференцій.

Оскільки самоізоляція жодним чином не перешкоджає, а тільки сприяє народженню нового покоління, то для опису тих, хто народився під час карантину i вступить у підлітковий вік у 2033-34 pр., виник неологізм quaranteen (з англ. quarantine - каратин i teen - підліток): "The quaranteens, Jed and Joe, were finally let out of isolation after the virus outbreak" [10]. Цей неологізм також уживають для найменування осіб, що народилися в період між 2001 і 2007 роками і стали підлітками під час пандемії COVID-19. Дітей, які були зачаті під час карантину, називають coronnials (з англ. corona - скорочення від coronavirus disease - коронавірусна хвороба та millennials - покоління Y, міленіали): "Pеople born into the generation of Coronnials are highly celebrated, as they represent human resilience in a time of great unknowns" [11].

Поширення хвороби COVID-19, упровадження обмежень, соціальний та економічний колапс призвели, на думку багатьох людей, до справжнього кінця світу. Закриття кордонів, скасування різноманітних заходів і порожні вулиці мегаполісів справили негативний вплив на психологічний стан багатьох людей, що в кінцевому результаті призвело до виникнення тривоги або навіть депресії. Такий важкий період у житті майже кожної людини почали називати coronapocalypse (від англ. corona - скорочення від coronavirus diseaseкоронавірусна хвороба й apocalypse - апокаліпcис), або ж coronageddon (від англ. corona - скорочення від coronavirus disease - коронавірусна хвороба й Armageddon - Армагеддон): "Тhe coronavirus COVID-19 that crushed China in 2019, set the rest of the world up for Coronageddon in 2020. It was a brutal time in World History" [12]; "During Coronapocalypse, we were confined in our homes and didn't get paid for a month" [13]. На відміну від тих, хто не вірить у повернення до звичайного плину життя, apocaloptimists (від англ. apocalypse - anoкаліпсис та optimist - onтиміст) - це позитивно налаштовані люди, які усвідомлюють усю серйозність ситуації, але, тим не менше, уважають, що життя після COVID-19 можливе: "Rather than jettisoning his likes and dislikes altogether, the apocaloptimist merely refuses to let them tyrannise him quite so much" [14].

Обмеження неодмінно викликають неоднозначну реакцію в соціумі. $€$ законослухняні громадяни, які завжди виконують всі правила заради порядку та благополуччя в громаді, а є такі люди, які нехтують своїм здоров'ям і здоров'ям оточуючих. Таким чином, у лексиці сучасної англійської мови з'явилися два нові слова для опису таких осіб covidiot ( 3 англ. covid (coronavirus disease) - коронавірусна хвороба та idiot - недотепа) та covidient (3 англ. covid (coronavirus disease) - коронавірусна хвороба й obedient - слухняний, покірний). Covidiot - це той, хто ігнорує застереження щодо охорони здоров'я та безпеки населення: “Did you see that covidiot with 300 rolls of toilet paper in his basket?" [15]. На противагу неологізму covidiot, слово covidient характеризує особу, яка дотримується всіх настанов уряду 3 профілактики інфікування й поширення захворювання на COVID-19. Наведемо приклад уживання цієї неолексеми:

Mum: "For the hundredth time today, wash your hands!"

You: "Mum stop being such a covidient" [16].

COVID-19 змусив багатьох людей навчитися адаптуватися до нестабільності в особистому i професійному житті. 3 метою запобігання розповсюдженню вірусу урядам довелося вводити нові обмеження у звичний розпорядок дня громадян. Самоізоляція та дотримання соціальної дистанції стали основною формою профілактики інфікування й поширення хвороби, спрямованої на захист уразливих груп населення. Словосполучення social distancing описує процес утримання від будь-яких контактів з іншими особами протягом певного періоду часу під час спалаху заразної хвороби: "The various measures of social distancing - reducing use of mass transit, closing schools, canceling public gatherings and isolating the sick - were examples of measures that in combination can reduce risk" [17]. Такі слова, як self-quarantine та self-isolate, $є$ найбільш часто вживаними в публікаціях у соціальних мережах, коментарях, новинах і звітах. Наведемо декілька прикладів: As the Coronavirus spreads fast, all those who have returned from foreign countries have been 
asked to self-quarantine to contain the outbreak [18]; Since you had contact with those who returned from France, you need to selfisolate for two weeks [18].

Окрім того, що пандемія COVID-19 є великою проблемою для галузі охорони здоров'я, вона має численні соціально-економічні та психологічні наслідки. Дослідження COVID-19 і повідомлення в ЗМІ виявили зростання побоювань, пов'язаних iз зараженням вірусом. В умовах карантину людей переслідує невизначеність, необхідність набуття нових практик, утрата віри в інфраструктуру охорони здоров'я, тривожність і невпевненість у кожному наступному дні. Таким чином, усі ці фактори призвели до надмірного занепокоєння з приводу фізіологічних симптомів, значного стресу, уникнення громадських заходів і транспорту, або ж, іншими словами, до coronaphobia (з англ. coronaскорочення від coronavirus disease - коронавірусна хвороба та phobia - фобія, страх): “Wow, we've lost half the audience to the show tonight due to coronaphobia" [19].

Хоча карантин та обмеження соціальних зв'язків $є$ необхідними засобами в боротьбі з пандемією COVID-19, вони не можуть тривати дуже довго. Неологізм covexit (з англ. covid - скорочення від coronavirus disease - коронавірусна хвороба та ехіtвихід) описує процес поступового послаблення та зняття обмежень у суспільному житті, накладених урядами у відповідь на кризу, пов'язану з хворобою COVID-19: "Perhaps, now is the time to start talking about "Covexit" as the title of an international set of principles and measures to be promoted to deal with the release in a structured way from Covid-19 lockdown" [20]. У мережі Інтернет з'явилося безліч соціальних сторінок і блогів, присвячених порадам щодо того, як безпечно вийти 3 поточної кризи, захистити себе і близьких від зараження вірусом i вберегти психічне здоров'я.

Висновки й перспективи подальших розробок. Дискурс пандемії COVID-19 є повноцінним продуктом мисленнєво-мовленнєвої діяльності індивідів, який утворився на тлі подій 2019-2021 pp. Досліджуваний дискурс має гібридну природу, оскільки в ньому інтегруються й перетинаються ознаки різних типів дискурсу, а саме: медичного, політичного, економічного, психологічного, освітнього, туристичного та побутового. Англомовний дискурс пандемії COVID-19 характеризується високим впливогенним потенціалом, мультимодальністю й неогенністю. Тексти коронавірусної тематики вирізняються насиченістю новими словами та словосполученнями. За структурою досліджувані неологізми - це складні слова, більшість із яких утворені поєднанням або скороченням двох основ. Вони позначають нові реалії життя, безпосередньо пов'язані з пандемією COVID-19. Подальші наукові пошуки можна спрямувати на дослідження особливостей відтворення неологізмів в англомовному дискурсі пандемії COVID-19 засобами української мови.

\section{ЛIТЕРАТУРА}

1. Бабелюк О.А., Дідух Л.І. Способи творення неологізмів на позначення явищ COVID-19 в англомовному епідеміологічному дискурсі. Львівський філологічний часопис. 2020. № 7. С. 5-12.

2. Весна Т.В., Телецька Т.В. Лексичні інновації періоду коронавірусної пандемії. Записки з романо-германської філологї. 2020. Т. 44. № 1. С. 82-89.

3. Красницька К., Степанюк Н., Долусова Н. Глобальне явище CORONAVIRUS як новий концепт в англомовній лінгвокогнітивній картині світу. Актуальні питання гуманітарних наук. 2020. Т. 1. № 32. С. 148-153.

4. Іванців О.В. Когнітивно-дискурсивні основи формування корпоративного іміджу (на матеріалі англомовних прес-релізів міжнародних косметичних компаній) : автореф дис. ... канд. філол. наук. Львів, 2016. 20 с.

5. Oxner R. Oxford's Defining Words Of 2020: 'Blursday', 'Systemic Racism' And Yes, 'Pandemic'. NPR. URL: https://www.npr. org/2020/11/23/938187229/oxfords-definingwords-of-2020-blursday-systemic-racism-andyes-pandemic? $t=1619049006045$.

\section{ДЖЕРЕЛА}

\section{ІЛЮСТРАТИВНОГО МАТЕРІАЛУ}

6. Glossary of 2020: The 36 New Words and Phrases That Defined the Year. Arts \& Culture. URL: https://www.thenationalnews.com/artsculture/glossary-of-2020-the-36-new-wordsand-phrases-that-defined-the-year-1.1134259.

7. Everything You Need to Know About Doomscrolling and How to Avoid It. Cleveland Clinic. URL: https://health.clevelandclinic. org/everything-you-need-to-know-aboutdoomscrolling-and-how-to-avoid-it/.

8. Kocher Ch. 'Zoombombing' Research Shows Legitimate Meeting Attendees Cause Most Attacks. Binghampton University News. URL: $\quad$ https://www.binghamton.edu/news/ story/2861/zoombombing-research-showslegitimate-meeting-attendees-cause-most-attacks.

9. Zoom fatigue. Urban Dictionary. URL: https://www.urbandictionary.com/define. php?term $=$ Zoom $\% 20$ Fatigue.

10. Quaranteen. Macmillan Dictionary. URL: https://www.macmillandictionary.com/ dictionary/british/quaranteen.

11. Coronnials. Urban Dictionary. URL: https://www.urbandictionary.com/define. php?term=coronnials. 
12. Coronageddon. Urban Dictionary. URL: https://www.urbandictionary.com/define. php?term $=$ Coronageddon.

13. Coronapocalypse. Urban Dictionary. URL: https://www.urbandictionary.com/author. php?author=Anony-Mouse007.

14. Apocaloptimism. https://www.newphilosopher. com/articles/apocaloptimism/.

15. Covidiot. Urban Dictionary. URL: https://www. urbandictionary.com/define.php?term=Covidiot.

16. Covidient. Urban Dictionary. URL: https://www.urbandictionary.com/define. php?term=Covidient.

17. Social distancing. Cambridge Dictionary. URL: https://dictionary.cambridge.org/ru/\%D1\%81\% D0\%BB $\%$ D0\%BE $\%$ D0\%B2\%D0\%B0\%D1\%80 $\% \mathrm{D} 1 \% 8 \mathrm{C} / \% \mathrm{D} 0 \% \mathrm{~B} 0 \% \mathrm{D} 0 \% \mathrm{BD} \% \mathrm{D} 0 \% \mathrm{~B} 3 \% \mathrm{D} 0 \%$ BB $\%$ D0\%B8\%D0\%B9\%D1\%81\%D0\%BA $\%$ D $0 \% \mathrm{~B} 8 \% \mathrm{D} 0 \% \mathrm{~B} 9 /$ social-distancing.

18. P'Rayan A. Coronavirus and the 'Words Outbreak': Are You 'Covidiot' or 'Covidient'? Edex Live. URL: https://www.edexlive.com/ opinion/2020/mar/24/covid-19-and-the-wordsoutbreak-are-you-covidiot-or-covidient-10846. html.

19. Coronaphobia. Urban Dictionary. URL: https://www.urbandictionary.com/define. php?term=coronaphobia.

20. Covexit. Macmillan Dictionary. URL: https://www.macmillandictionary.com/ dictionary/british/covexit.

\section{REFERENCES}

1. Babeliuk, O. A, Didukh, L. I. (2020) Ways of word-formation of neologisms naming COVID-19 phenomena in English epidemiological discourse [Sposoby tvorennia neolohismiv na poznachennia yavyshch COVID-19 v anhlomovnomu epidemiolohichnomu dyskursi]. Lviv Philology Journal. № 7. P. 5-12.

2. Vesna, T. V., Teletska, T. V. (2020) Lexical innovations of the coronavirus pandemic period [Leksychniinnovatsiyi period koronavirusnoyi pandemiyi]. Writings in Romance-Germanic Philology. V. 44, № 1. P. 82-89.

3. Krasnytska, K, Stepaniuk, N, Dolusova N. (2020) Global phenomenon of CORONAVIRUS as a new concept in English linguocognitive picture of the world [Hlobalne yavyshche CORONAVIRUS yak novyi kontsept v anhlomovniy linhvokohnityvniy kartyni svitu]. Topical Issues in the Humanities. V. 1, № 32. P. 148-153.

4. Ivantsiv, O. V. (2016) Cognitive-discursive foundations of corporate image formation (based on the texts of English press releases of international cosmetic companies) [Kohnityvno-dyskursyvni osnovy formuvannia korporatyvnoho imidzhu (na materiali anhlomovnyh pres-reliziv miznarodnyh kosmetychnyh kompaniy]. [Dissertation, Lviv].

5. Oxner R. Oxford's Defining Words Of 2020: 'Blursday', 'Systemic Racism' And Yes, 'Pandemic'. NPR. URL: https://www.npr. org/2020/11/23/938187229/oxfords-definingwords-of-2020-blursday-systemic-racism-andyes-pandemic $\mathrm{t}=1619049006045$. 